\title{
METODE PENGENDALIAN ATENSI PESERTA DIDIK DALAM PEMBELAJARAN PAI MATERI MUHAMMAD SAW (ANALISIS TERHADAP VARIASI TEKNIK PENYAMPAIAN HADIS)
}

\author{
Purnomo \\ Institut Agama Islam Negeri Salatiga \\ purnomo@iainsalatiga.ac.id
}

Diterima: 7 Agustus 2019 | Direvisi: 21 Oktober 2019 | Disetujui: 25 November 2019

(C) 2018 Program Studi Pendidikan Agama Islam Fakultas Agama Islam Universitas Islam Malang

\begin{abstract}
The implementation of Islamic education still faces various problems, for example students who often pay no attention to lessons. This is one of the challenges for the teachers. One of the educators who can be used as an example to overcome this problem is Muhammad pbuh. Attention control applied by Muhammad pbuh is supported by jawami'ul kalim (concise words with meaningful meaning), and qaulan baligha (words that imprint in the heart). This study uses a text study method with functionalist pragmatic data analysis technique consisting of interpretation and holistic stages. Interpretation, namely diving a text message according to research needs. Holistic, that is interpretation by positioning the text as a product of the interaction of all the surrounding reality. The method of data collection in this study is to collect various primary and secondary sources that are related to the object of research. This research shows that attention control which Muhammad pbuh has applied has a meeting point with various theories of attention. The technique includes (1) repetition, (2) interactive dialogue with rhetorical questions (3) utilization of momentum, (4) mention of global things, (5) displaying abnormalities and surprises, and (6) touching the communicant.
\end{abstract}

Keyword: Methods, Attention Control, PAI Learning

\begin{abstract}
Abstrak
Implementasi pendidikan Islam masih menghadapi berbagai masalah, misalnya siswa yang sering tidak memperhatikan pelajaran. Ini adalah salah satu tantangan bagi para guru. Salah satu pendidik yang bisa dijadikan contoh untuk mengatasi masalah ini adalah Muhammad SAW. Kontrol perhatian yang diterapkan oleh Muhammad SAW didukung oleh jawami'ul kalim (kata-kata singkat dengan makna yang bermakna), dan qaulan baligha (kata-kata yang membekas di hati). Penelitian ini menggunakan metode studi teks dengan teknik analisis data pragmatis fungsional yang terdiri dari tahapan interpretasi dan holistik. Interpretasi, yaitu menyelam pesan teks sesuai dengan kebutuhan penelitian. Holistik, yaitu interpretasi dengan memposisikan teks sebagai produk dari interaksi semua realitas di sekitarnya. Metode
\end{abstract}


pengumpulan data dalam penelitian ini adalah dengan mengumpulkan berbagai sumber primer dan sekunder yang terkait dengan objek penelitian. Penelitian ini menunjukkan bahwa kontrol perhatian yang diterapkan Muhammad SAW memiliki titik temu dengan berbagai teori perhatian. Teknik ini meliputi (1) pengulangan, (2) dialog interaktif dengan pertanyaan retoris (3) pemanfaatan momentum, (4) penyebutan hal-hal global, (5) menampilkan kelainan dan kejutan, dan (6) menyentuh komunikasi..

Kata Kunci: Metode, Pengendalian Atensi, Pembelajaran PAI

\section{Pendahuluan}

Salah satu masalah yang sering ditemui guru adalah adanya peserta didik yang tidak atau kurang memperhatikan pelajaran, terlihat jenuh, letih, bosan atau lesu. Keadaan semacam itu merupakan efek dari banyaknya stimulus yang ditawarkan kepada peserta didik (Jensen, 2008: 188). Apabila semua stimulus berakhir di working memory maka mustahil diproses dengan baik oleh sumber daya otak yang terbatas (Woolfolk, 2009: 9).

Sistem dalam otak manusia, sebagaimana sebuah mesin, berfungsi dengan baik apabila stimulus yang diproses berada pada rentang kemampuan tertentu. Otak perlu berfokus pada stimulus tertentu dan mengabaikan stimulus lainnya. Kemampuan memilih stimulus tertentu untuk menyesuaikan kapasitas otak disebut sebagai atensi (Johnson, 2004: 294). Hal inilah yang menjadikan atensi sebagai faktor penting untuk meningkatkan efektifitas pembelajaran. Pembelajaran membutuhkan proses kerja otak yang ideal dan maksimal melalui pemusatan atensi.

Peran penting atensi dalam proses belajar dikuatkan oleh Johnson (2004: 301) yang menyatakan bahwa keberhasilan mengendalikan atensi akan berpengaruh besar terhadap pengembangan kecerdasan berpikir secara umum. Kegiatan belajar peserta didik yang menuntut proses berpikir ilmiah secara otomatis membutuhkan adanya atensi. Tingkat atensi peserta didik dalam kegiatan tersebut ditentukan oleh metode guru dalam mengajar (Oestinsih, 2008: 60). Untuk itu pendidik dituntut untuk mengusai teknik pengendalian atensi peserta didik sehingga mampu mewujudkan pembelajaran yang baik.

Salah satu pendidik yang terbukti menguasai pengendalian atensi peserta didik adalah Muhammad saw. Hal ini ditegaskan dalam Surah AnNisa' [4]: 63, "Mereka itu adalah orang-orang yang Allah mengetahui apa yang di dalam hati mereka. Karena itu berpalinglah kamu dari mereka, dan 
berilah mereka pelajaran, dan katakanlah kepada mereka perkataan yang berbekas pada jiwa mereka (qaulan baligha)."

Qaulan baligha (perkataan yang berbekas pada jiwa mereka) merupakan kemampuan berbahasa yang mendukung pengendalian atensi. Hamka (2008: 142) menyebutkan bahwa ungkapan qaulan baligha bermakna ucapan yang fasih dan tepat sehingga menyentuh perasaan komunikan. Kemampuan berkomunikasi yang baik adalah salah satu kemampuan dasar para nabi sebagaimana disebutkan dalam Surah Ibrahim [14]: 4, "Tidak Kami utus seorang rasul kecuali ia harus menjelaskan dengan bahasa kaumnya." Berbahasa sesuai bahasa kaumnya bukan hanya dimaknai dengan menggunakan rumpun bahasa yang sama tapi juga sesuai dengan kondisi komunikan. Muhammad saw. menegaskan kesadarannya mengenai hal ini dalam hadis, "Berbicaralah kepada manusia sesuai dengan pengetahuan mereka" (HR. Bukhari: 124).

Selain qaulan baligha, kemampuan Muhammad saw. dalam mengelola atensi berkaitan erat dengan penguasaan jawami'ul kalim. Muhammad saw. berkata, "Aku diutus dengan jawami'ul kalim" (HR. Bukhari: 2755). Jawami'ul kalim adalah kalimat yang ringkas namun mengandung makna yang banyak, padat dan mendalam. Hadis riwayat Muslim nomor 5325 menginformasikan bahwa kata-kata Muhammad saw. cukup ringkas hingga dapat dihitung. Redaksi yang singkat menjadi bagian yang mempengaruhi atensi karena kesederhanaan redaksi mempermudah komunikan membangun persepsi kemudian membentuk atensi.

Keseluruhan paparan tentang kemampuan berkomunikasi Muhammad saw. mengisyaratkan bahwa ia mampu mengendalikan atensi lawan bicaranya dengan baik. Berdasarnya latar belakang tersebut maka peneliti memandang perlunya satu ananlisis mendalam tentang pengendalian atensi peserta didik oleh Muhammad saw. merujuk pada variasi teknik penyampaian hadis.

\section{Metode}

Penelitian ini temasuk kategori studi/analisis teks. Menurut Noeng Muhadjir (1996: 158) studi/analisis teks adalah studi tentang persepsi manusia, upaya penstrukturan diri dan lingkungan manusia serta tentang pemberian makna lingkungan, atau telaah ilmu-ilmu kemanusiaan. Dalam pemaknaan yang luas, studi teks mencakup telaah pustaka ilmu-ilmu kemanusiaan, seperti psikologi, antropologi sampai studi teks dalam makna studi linguistik dan sastra.

Dalam studi ini teks tidak hanya dipandang sebagai objek bebas yang tidak memiliki makna lain di balik dirinya, akan tetapi teks juga dipandang 
sebagai representasi dari kelompok/individu atau menggambarkan ciri situasi yang diteliti (Titscher, 2009: 38). Dengan demikian, studi ini akan ditekankan pada pencarian makna tersirat di balik teks hadis yang berkaitan dengan teknik pengendalian atensi oleh Muhammad saw.

\section{Pembahasan}

\section{Atensi}

Atensi (Inggris: attention, Latin: attention, dari attendere yang secara harfiah berarti memperhatikan) adalah suatu keadaan mental seorang yang mampu mengarahkan atau memusatkan kegiatan kognitif dan praktisnya (fokus) pada suatu objek atau tindakan tertentu (Bagus, 1996: 96 dan Woolfolk, 2009: 9). Dengan demikian atensi dapat diibaratkan sebuah saringan (filter) untuk berbagai stimulus yang manusia tangkap.

Selaras dengan definisi tersebut, Johnson (2004: 294) memaknai atensi sebagai kemampuan untuk menghadirkan salah satu stimulus dalam pikiran dengan mengabaikan stimulus yang lain karena terbatasnya kapasitas otak. Atensi juga didefinisikan sebagai konsentrasi aktivitas mental (Matlin, 1994: 43). Dari semua definisi tersebut dapat diambil satu kesimpulan bahwa atensi adalah aktivitas mental yang berfokus pada stimulus tertentu dengan mengabaikan stimulus-stimulus lainnya.

\section{Pembelajaran Muhammad SAW}

Pembelajaran adalah proses yang dilakukan pendidik untuk membuat proses belajar di dalam diri peserta didik (Purwanto, 2008: 39). Pembelajaran dapat diartikan pula sebagai sebuah upaya sengaja oleh pendidik untuk menyampaikan ilmu pengetahuan, mengorganisasi dan menciptakan sistem lingkungan (Sugiharto dkk. (2007: 80). Proses tersebut dilaksanakan dengan berbagai metode sehingga peserta didik mampu belajar secara efektif dan efisien dengan hasil optimal.

Pembelajaran Muhammad saw. yang dimaksud dalam penelitian ini adalah serangkaian proses yang dilakukan oleh Muhammad saw. untuk membuat proses belajar terjadi dalam diri peserta didik yaitu para obyek dakwahnya. Segala sesuatu yang disandarkan kepada Muhammad saw. disebut sebagai hadis (Al-Qaththan, 2015: 22). Dengan demikian yang dimaksud dengan pengendalian atensi dalam pembelajaran Muhammad saw. adalah pengendalian atensi dalam penyampaian hadis.

\section{Penyampaiannya Hadis yang Menggunakan Pengendalian Atensi}

Muhammad saw. menggunakan berbagai macam teknik ketika menyampaikan hadis. Hal ini terkait dengan beraneka ragamnya kondisi komunikan maupun lingkungan yang dihadapi Muhammad saw. Berikut 
beberapa teknik yang Muhammad saw. gunakan untuk menarik atensi komunikan ketika menyampaikan hadis.

a. Pengulangan

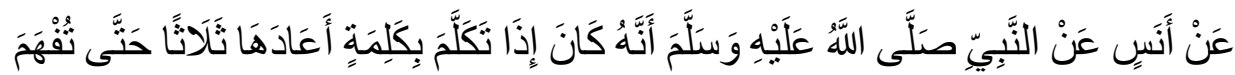

Artinya: dari Anas dari Nabi saw., bahwa Nabi saw. bila berbicara diulangnya tiga kali hingga dapat dipahami. (HR. Bukhari: 93).

Hadis di atas menyebutkan bahwa Muhammad saw. mengulangi perkataan hingga orang-orang mengerti, padahal mengerti atau memahami tidak akan tercapai tanpa memperhatikan. Otak tidak mungkin memproses informasi yang tidak terlebih dulu diperhatikan, dikenali dan dipersepsikan. Dalam beberapa hadis bahkan Muhammad saw. mengulangi perkataannya hingga shahabat berpikir untuk menyuruhnya diam.

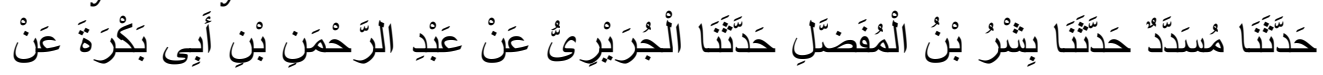

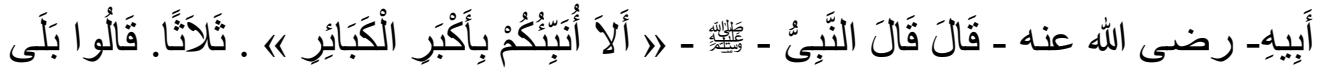

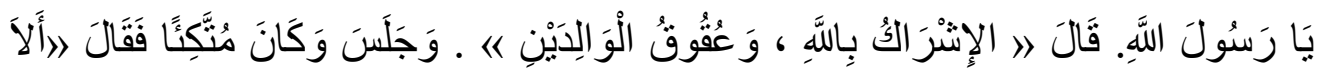

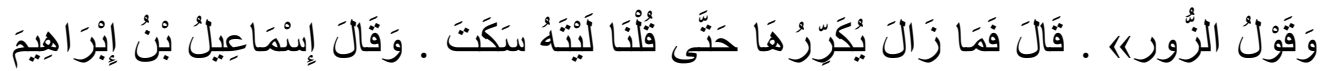

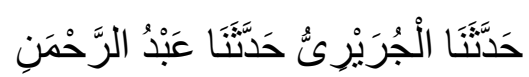

Artinya: Dari Musadaad, dari Bisr bin Al Mufadhal. Dari Juraij, dari Abdirrahman bin Abi Bakar, dari ayahnya, dia berkata bahwa Rasulullah bersabda, "Maukah kalian aku beritahukan mengenai dosa besar yang paling besar?" Beliau mengulanginya sebanyak tiga kali. Mereka menjawab, "Ya, wahai Rasulullah." Lalu beliau bersabda, "Yaitu, menyekutukan Allah dan durhaka terhadap kedua orangtua." Kemudian beliau duduk sambil bersandar, lantas bersabda, "Jauhilah perkataan dusta!" Abu Bakrah berkata, "Tiada henti-hentinya beliau mengulangulangi perkataan ini hingga kami berkata, "Semoga beliau diam." Ismail bin Ibrahim berkata, "Al Jurairi menceritakan kepada kami, Abdurrahman menceritakan kepada kami." (HR. Bukhari: 2460).

Muhammad saw. menggunakan pengulangan dalam rangka mengarahkan atensi lawan bicaranya pada apa yang ia katakan. Pengulangan tersebut terkadang dilakukan lebih dari tiga kali, tergantung kebutuhan. Pengulangan sebagian matan atau seluruhnya merupakan teknik yang cukup sering Muhammad saw. gunakan.

Atensi seseorang bergantung pada tingkat keuntungan yang diraih dari suatu stimulus (Hilgart, 1962: 210). Keuntungan tersebut di antaranya diukur melalui pengulangan. Hal ini dipengaruhi oleh karakter otak yang kemampuan fokusnya relatif berubah-ubah. Ketika mendengar 
satu kata atau kalimat tertentu seringkali otak tidak langsung meresponnya namun dalam kesempatan selanjutnya ketika kalimat tersebut diulang, atensi terhadap kalimat tersebut mulai meningkat.

Rakhmat (2005: 53) menyatakan bahwa pengulangan mengandung unsur sugesti (mempengaruhi bawah sadar), sehingga hal yang diulangulang tersebut akan berpengaruh kuat pada kondisi psikologis seseorang. Perkataan yang diulang-ulang selain membantu mengarahkan fokus juga membentuk sugesti bahwa hal itu penting untuk diperhatikan. Dengan demikian, pengulangan akan menarik atensi orang yang mendengarnya. Selain itu, pengulangan (repetisi) juga memberikan penguatan tentang pentingnya materi tersebut.

Contoh lain hadis yang menggunakan teknik repetesi (pengulangan) adalah sebagai berikut,

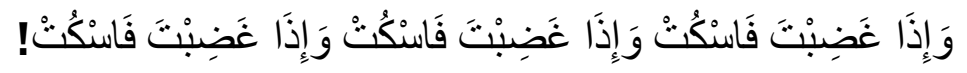

Artinya: Dan jika kamu marah, maka diamlah. Dan jika kamu marah, maka diamlah. Dan jika kamu marah maka diamlah! (HR. Ahmad: 2425)

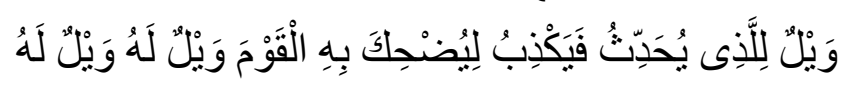

Artinya: dan celakalah orang yang berbicara lalu ia berdusta untuk membuat orang-orang tertawa. Celakalah dia! Celakalah dia! (HR. Ahmad: 19216)

Repetisi tidak hanya bermanfaat untuk mendapatkan atensi komunikan. Ghuddah (2009: 78) menjelaskan bahwa pengulangan (repetisi) dapat memberi penekanan pada materi yang disampaikan, agar dihapal dan lebih meresap dalam benak komunikan.

b. Dialog-Interkatif dengan pertanyaan retoris

Teknik dialog-interaktif sering digunakan oleh Muhammad saw. dalam forum pengajarannya dalam rangka menarik dan menjaga atensi peserta didik. Dalam beberapa kesempatan Muhammad saw. memulai dialog dengan terlebih dahulu melemparkan pertanyaan-pertanyaan yang sebenarnya telah diketahui jawabannya (retorika) untuk mendapatkan atensi lawan bicaranya.

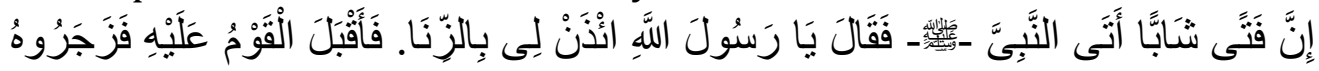

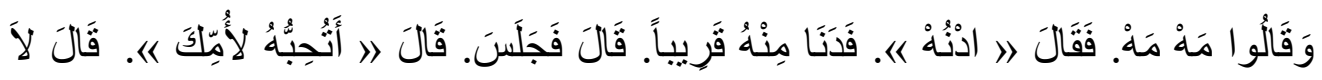

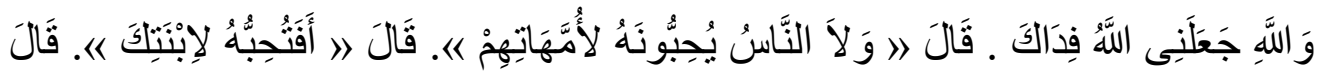

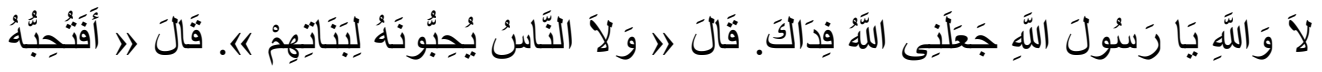

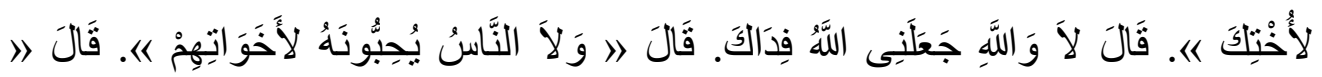




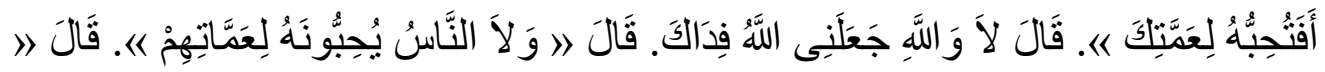

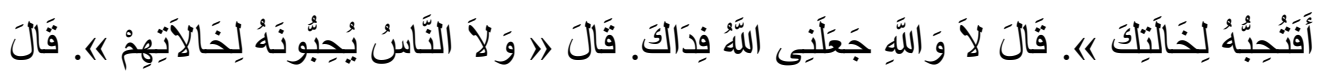

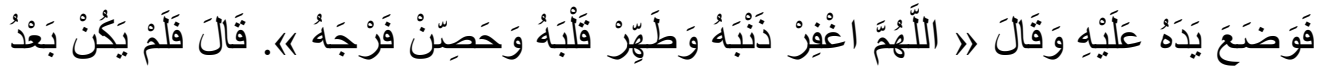

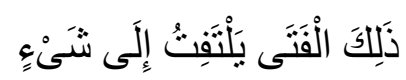

Artinya: sesungguhnya seorang pemuda telah datang kepada Nabi saw. lalu berkata, "Wahai Rasulullah saw. ijinkan aku berbuat zina." (mendengar perkataan tersebut) sekelompok orang mencelanya dan berkata, hentikan dan cegahlah dia. Rasulullah saw. kemudian berkata kepada orang itu, "Mendekatlah kepadaku!" Pemuda itu mendekat dan duduk di hadapan Rasulullah saw. Ia saw. bertanya, "Apakah Engkau senang jika yang dizinai itu ibumu?" Pemuda itu menjawab, "Tidak demi Allah, wahai Rasulullah saw., lebih baik aku menjadi tebusanmu saja!" Kemudian beliau menjelaskan orang-orang pun juga tidak akan rela jika yang dizinai adalah ibu mereka. Ia saw. bertanya lagi, "Apakah Engkau senang jika yang dizinai itu anak perempuanmu?" Pemuda itu menjawab, tidak demi Allah, wahai Rasulullah saw., lebih baik aku menjadi tebusanmu saja!" Kemudian ia saw. menjelaskan manusia mana pun juga tidak akan rela jika yang dizinai adalah anak perempuan mereka.

Muhammad saw. bertanya, "Apakah Engkau senang jika yang dizinai itu saudara perempuanmu?" Pemuda itu menjawab, "Tidak demi Allah, wahai Rasulullah saw., lebih baik aku menjadi tebusanmu saja!" Kemudian ia saw. menjelaskan siapa pun tidak akan rela jika yang dizinai adalah saudara perempuan mereka. Beliau bertanya lagi, "Apakah Engkau senang jika yang dizinai itu bibimu (dari pihak ayah)?" Pemuda itu menjawab, "Tidak demi Allah, wahai Rasulullah saw., lebih baik aku menjadi tebusanmu saja!" Kemudian ia saw. menjelaskan orang-orang pun juga tidak akan rela jika yang dizinai adalah bibi (dari pihak ayah) mereka. Ia saw. bertanya lagi, "Apakah Engkau senang jika yang dizinai itu bibimu (dari pihak ibu)?" Pemuda itu menjawab, "Tidak demi Allah, wahai Rasulullah saw., lebih baik aku menjadi tebusanmu saja!" Kemudian ia saw. menjelaskan orang-orang pun juga tidak akan rela jika yang dizinai adalah bibi (dari pihak ibu) mereka.

Setelah itu ia saw. meletakkan tangan beliau di atas pundak pemuda tersebut seraya berdoa, "Ya Allah, ampunilah dosanya, bersihkan hatinya dan jagalah kemaluannya." Sejak itu tidak pernah terbesit sedikitpun pada pemuda tersebut untuk berzina. (HR. Ahmad: 21185).

Dalam hadis ini Muhammad saw. memulai percakapan dengan mengajukan berbagai pertanyaan yang mampu memancing atensi. Muhammad saw. menanyakan satu persatu mengenai persetujuannya 
jika beberapa kerabat perempuannya dizinai. Hal ini tentu sangat mengusik emosi seseorang dan akhirnya menjadikannya perhatian dengan dialog yang berlangsung. Menurut Jensen (2008: 192) sesuatu yang memiliki makna personal bagi seseorang akan mampu menarik atensinya.

Dari pertanyaan pertama yang Muhammad saw. lontarkan, sang pemuda langsung memberikan respon serius yang dibuktikan dengan penggunaan sumpah. Respon semacam ini menunjukkan bahwa sang pemuda menaruh atensi dengan perkataan Muhammad saw. Atensi pemuda tersebut tetap terjaga pada pertanyaan-pertanyaan Muhammad saw. sampai akhir dialog yakni ketika Muhammad saw. berdo'a agar pemuda itu tidak ingin berzina lagi. Semakin baik pertanyaan maka akan semakin besar pengaruhnya dalam menarik atensi sehingga keberadaan jawami'ul kalim dan qaulan baligha sangat berperan dalam teknik ini.

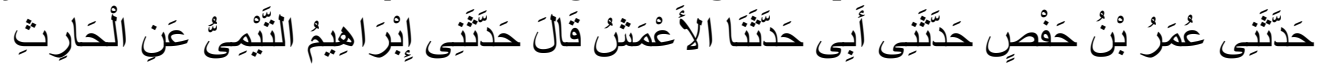

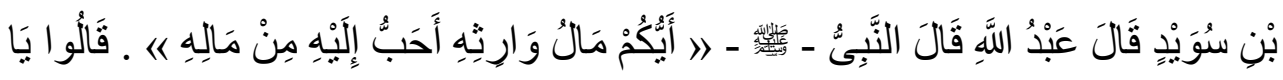

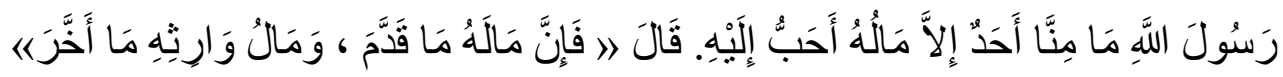

Artinya: "Siapakah diantara kalian yang harta warisnya lebih dia cintai daripada hartanya sendiri?" Mereka menjawab, "Wahai Rasulullah, tidak ada seorang pun dari kami melainkan hartanya lebih dia cintai." Beliau bersabda, "sesungguhnya hartanya adalah segala yang telah dipersembahkannya (untuk kehidupan akhirat), sedangkan harta warisnya adalah harta yang dipersembahkannya untuk selain hal itu." (HR. Bukhari: 5961).

Dalam hadis tersebut Muhammad saw. tidak secara langsung membahas mengenai pesan utama namun memulainya dengan sebuah dialog retoris yang serta merta mendapat respon dari para shahabat. Dalam peristiwa tersebut tersirat adanya upaya Muhammad saw. untuk memusatkan perhatian shahabat terhadap diri dan perkataannya. Muhammad saw. tidak ingin menyampaikan sesuatu yang penting ketika para shahabat belum menaruh perhatian padanya.

De Porter dan Singer (1990: 155) menyatakan bahwa pada dasarnya seorang guru bertanya dengan dua tujuan yakni: untuk menghargai peserta didik dan membuka pikiran peserta didik dalam tingkatan yang lebih tinggi. Dengan demikian, melontarkan pertanyaan memberikan kesempatan kepada Muhammad saw. untuk membuat lawan bicaranya merasa dihargai. Orang yang ditanya juga akan merasa partisipasi/keberadaannya diperhitungkan. Dengan demikian ia akan menaruh atensinya terhadap pihak yang bertanya. Dalam filosofi dalam 
Huruf Jawa dikenal istilah "bakalan mati yen dipangku", seseorang akan tunduk dan memberi perhatian penuh kepada orang lain yang membuatnya merasa dihargai atau ditinggikan derajatnya.

Selanjutnya, dengan bertanya Muhammad saw. akan membuka pikiran lawan bicaranya, sekaligus memberikan gambaran tentang pembahasan yang akan dilakukan. Hal ini Ilahi (2010: 183) akan mendorong lawan bicara untuk mamahami, berpikir dan menaruh atensi. Muhammad saw. tidak hanya menjadikan pertanyaan sebagai pembuka dialog namun juga melihat kesiapan atensi lawan bicaranya. Melontarkan pertanyaan yang disertai kerangka untuk menjawabnya disebut Woolfolk (2009:13) sebagai salah satu pedoman dalam menarik dan mempertahankan atensi komunikan.

Tanya jawab menjadikan peserta didik benar-benar telibat dalam pembelajaran. Hal semacam ini menurut Silberman (2005: 81) akan menjaga atensi peserta didik. Keterlibatan peserta didik juga memunculkan keingintahuan dan merangsang proses berpikir secara aktif. Hal ini menunjukkan bahwa dialog tidak hanya mampu menarik atensi namun juga membantunya tetap terjaga selama proses pembelajaran.

c. Mengemukakan Hal yang Global

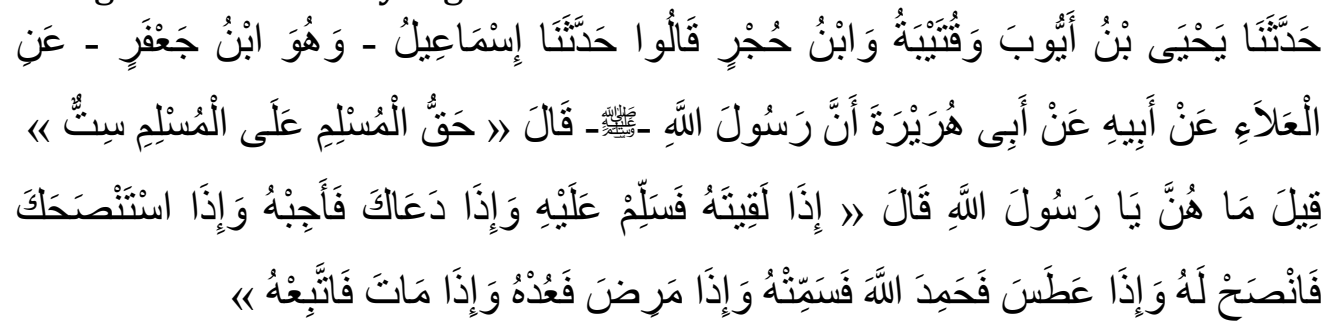

Artinya: Dari Yahya bin Ayyub, dari Qutaibah, dari Ibnu Khudri, dari Ismail (anak Ja'far), dari Alai, dari ayahnya, dari Abu Hurairah sesungguhnya Rasulullah bersabda: "Hak seorang muslim yang harus dipenuhi oleh muslim lainnya ada enam." Ditanyakan, "Apakah keenam hak itu wahai Rasulullah?" Beliau bersabda, "Jika engkau berjumpa dengannya maka ucapkanlah salam, jika ia mengundang maka penuhilah undangannya, jika ia meminta nasihat kepadamu maka nasihatilah, jika ia bersin lalu memuji Allah maka ucapkanlah: yarhamukallah, jika ia sakit maka kunjungilah, dan jika ia mati maka antarkanlah jenazahnya." (HR. Muslim: 4023)

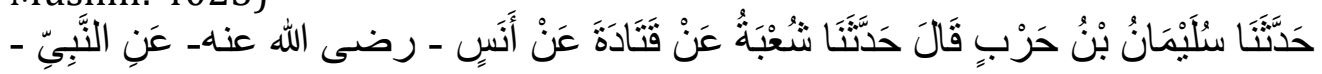

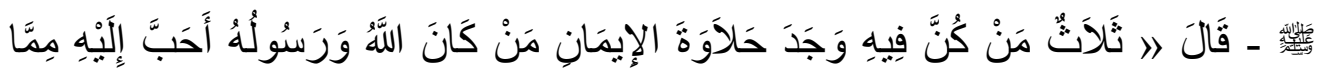




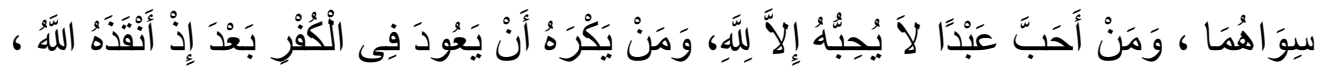

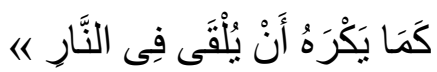

Artinya: Ada tiga hal yang jika ketiganya terdapat pada diri seseorang maka dia akan merasakan manisnya iman: 1) Allah dan RasulNya lebih dia cintai daripada selain keduanya, 2) mencintai seseorang dengan niat hanya karena Allah semata, 3) tidak menyukai kembali ke dalam kekufuran sebagaimana tidak menyukai jika dilemparkan ke dalam api. (HR. Bukhari: 15).

Ilahi (2010: 165) berpendapat bahwa dengan menyebutkan hal global sebelum menerangkan sesuatu akan membangkitkan rasa ingin tahu dan memberikan gambaran awal mengenai inti pembahasan. Selain itu Ghuddah, (2009: 199) menambahkan bahwa teknik semacam itu akan membuat peserta didik termotivasi, terangsang dan menaruh perhatian.

Ketika global materi telah disebutkan maka peserta didik akan mendapat gambaran mengenai pentingnya materi. Hal tersebut akan membetuk sebuah persepsi yang dikomparasikan dengan ingatan jangka panjang (pengalaman). Jika terjadi kecocokan di antara keduanya maka otak akan memulai proses atensi terhadap stimulus tadi. Penyebutan hal yang global di awal pembicaraan adalah pemberian sebuah ruang untuk membangun persepsi. Persepsi adalah inti dalam komunikasi. Persepsi menurut DeVito (1997: 75) menjadikan manusia sadar akan banyaknya stimulus yang mempengaruhi inderanya. Dengan kata lain, persepsi adalah titik mula atensi.

Menurut Jensen (2008: 131) manusia tidak akan pernah memahami sesuatu secara kognitf sampai ia dapat menciptakan sebuah model atau metafora. Hal ini disebabkan karena korteks otak memiliki kemampuan untuk mendeteksi dan menciptakan pola makna. Ketika Muhammad saw. menyebutkan hal secara global, sejatinya ia telah memberi petunjuk kepada otak lawan bicaranya untuk mengurai dan mencari hubungannya dengan informasi yang sebelumnya telah diketahui. Kemudian terjadi runtutan proses menuju atensi. Penyebutan hal global di awal sebuah pembicaraan sama halnya dengan sebuah judul dalam sebuah tulisan yang menggiring pembaca untuk melanjutkan membaca atau tidak. Dengan demikian teknik ini pada sangat bergantung pada daya pikat kalimat global yang dimunculkan, apakah ia cukup kuat untuk dipersepsikan sebagai hal yang menarik atau tidak.

Teknik ini mudah ditemui dalam berbagai hadis seperti hadis tentang empat ciri munafik, tujuh golongan yang mendapat naungan Allah di akhirat, sepuluh shahabat yang dijamin masuk surga, tanda- 
tanda kiamat dsb. Yang perlu digarisbawahi dari teknik ini, begitu dengan teknik yang lainnya, Ialah Muhammad saw. senantiasa menjada ritme dan tempo bicaranya sehingga ada jeda antara penyebutan hal global dan rinciannya. Hal ini memberi waktu bagi komunikan untuk terlebih dulu membangun persepsi.

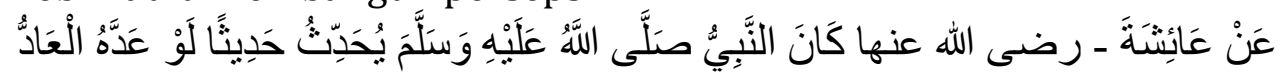

Artinya: Diriwayatkan dari Aisyah ra, Nabi saw. hanya menyampaikan suatu hadis, bila seseorang menghitungnya pasti bisa. (HR. Muslim: 5325).

d. Menampilkan ketidaknormalan dan kejutan

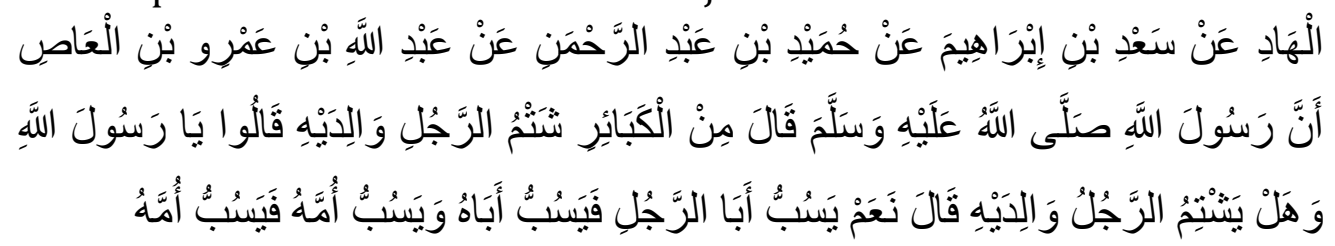

Telah menceritakan kepada kami Qutaibah bin Sa'id telah menceritakan kepada kami al-Laits dari Ibnu al-Had dari Sa'ad bin Ibrahim dari Humaid bin Abdurrahman dari Abdullah bin Amru bin alAsh bahwa Rasulullah saw. bersabda, "Di antara dosa besar adalah seorang laki-laki mencela kedua orang tuanya." Para shahabat bertanya, "Wahai Rasulullah, 'Apakah (mungkin) seorang laki-laki mencela orang tuanya?' Beliau menjawab: "Ya. Dia mencela bapak seseorang lalu orang tersebut (membalas) mencela bapaknya, lalu dia mencela ibunya, lalu orang tersebut (membalas) mencela ibunya." (HR. Muslim: 130)

Ketika mendengar pernyataan tentang dosa mencela orang tua, seorang shahabat langsung tersedot atensinya karena menganggap pernyataan Muhammad saw. tidak lazim. Menurut Shimp (2003: 146) ketidaklaziman akan meningkatkan daya tarik stimulus untuk diperhatikan. Setelah atensi shahabat timbul dalam ekspresi keheranan, Muhammad saw. kemudian menjelaskan bahwa walaupun jarang terjadi seseorang menghina orang tuanya secara langsung, tetapi bisa saja dia menjadi penyebab kedua orang tuanya dicela, dan ini mungkin sering terjadi.

Menurut Jensen (2008: 189) salah satu hal yang menarik atensi adalah sesuatu yang aneh (tidak normal) atau asing. Ketidaknormalan dan kejutan dalam konteks ini dimaknai dengan memunculkan hal yang tidak biasa, berbeda dan tidak bisa diprediksi. Hal tersebut bersesuaian dengan pendapat Suryabrata (2008: 17) yang mengatakan bahwa atensi seseorang dapat ditarik oleh sesuatu yang lain dari keadaan lainnya atau yang keluar dari konteksnya. Pendapat ini dapat dikaitan dengan adanya 
perbedaan intensitas stimulus yang 'tidak normal' tersebut dengan latar belakangnya atau dengan stimulus-stimulus lain yang 'normal' sehingga stimulus yang 'tidak normal' tampak lebih mudah diidenfikasi dan perhatikan.

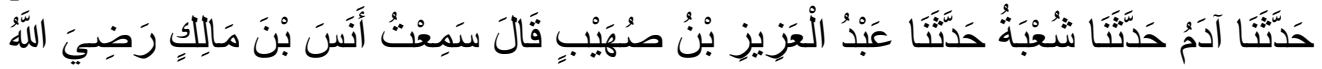

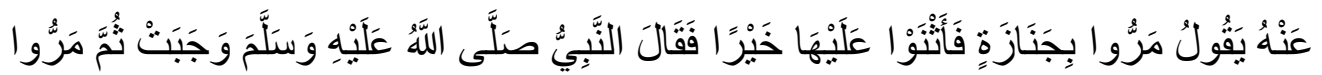

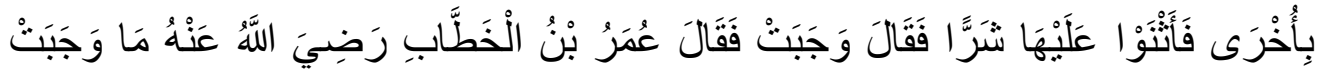

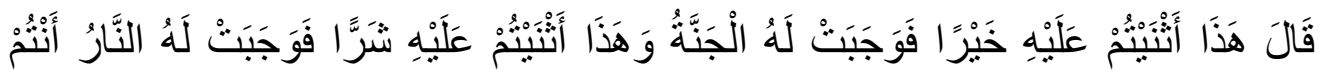

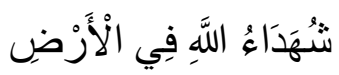

Telah menceritakan kepada kami Adam telah menceritakan kepada kami Syu'bah telah menceritakan kepada kami 'Abdul 'Aziz bin Shuhaib berkata, "Aku mendengar Anas bin Malik radliallahu 'anhu berkata, "Mereka (para shahabat) pernah melewati satu jenazah lalu mereka menyanjungnya dengan kebaikan. Maka Nabi saw. bersabda, "wajabat". Kemudian mereka melewati jenazah yang lain lalu mereka menyebutnya dengan keburukan, maka Beliaupun bersabda, "wajabat". Maka kemudian 'Umar bin Al Khaththab radliallahu 'anhu bertanya, "Apa yang dimaksud dengan wajabat?" Beliau menjawab, "Jenazah pertama kalian sanjung dengan kebaikan, maka pasti baginya (wajabat) masuk surga sedang jenazah kedua kalian menyebutnya dengan keburukan, berarti dia masuk neraka karena kalian adalah saksi-saksi Allah di muka bumi". (HR. Bukhari: 1278).

Keanehan yang muncul di awal riwayat ini ialah adanya persamaan pernyataan yang Muhammad saw. sampaikan bagi kedua mayat padahal mereka memiliki amal yang bertolak belakang namun seakan-akan mereka akan mendapat ganjaran yang sama karena sama-sama dido'akan dengan redaksi yang sama. Keanehan inilah yang kemudian menarik perhatian 'Umar hingga akhirnya menaruh atensi dan bertanya.

Dalam Shahih Muslim nomor 1578, kata "wajabat" (pasti baginya) diulangi sebanyak tiga kali. Dengan demikian Muhammad saw. tidak selalu hanya menggunakan satu teknik pengendalian atensi dalam satu waktu.

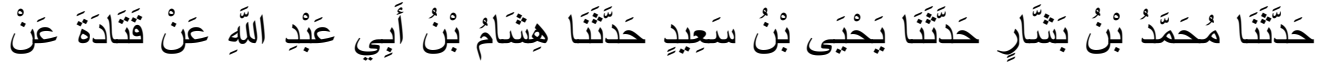

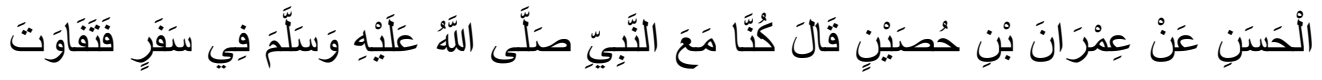

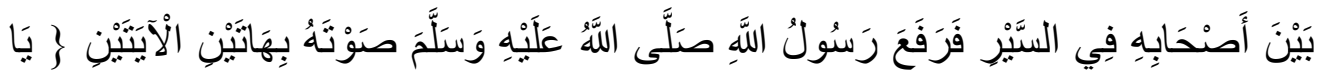

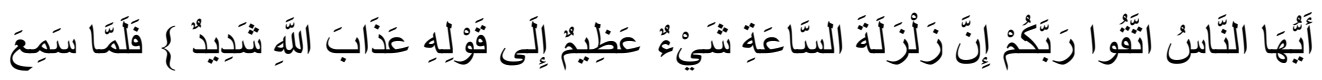

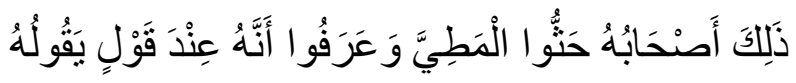




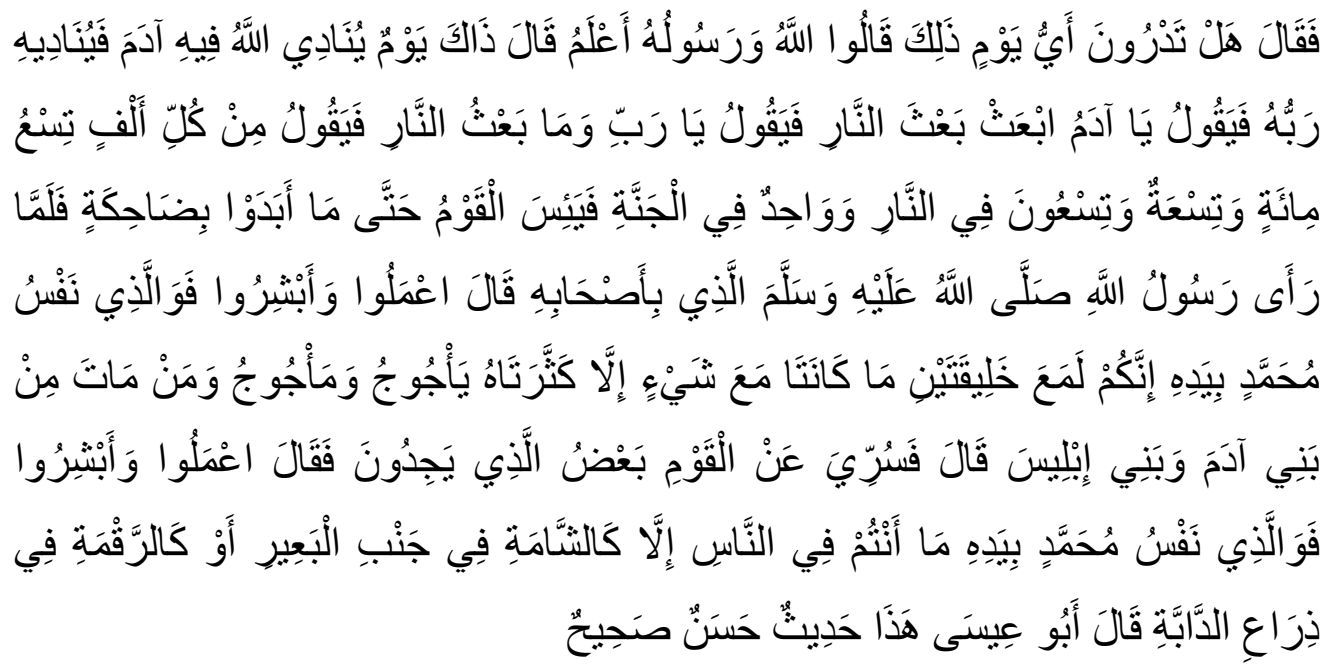

Telah menceritakan kepada kami Muhammad bin Basyar telah menceritakan kepada kami Yahya bin Sa'id telah menceritakan kepada kami Hisyam bin Abu Abdullah dari Qatadah dari Al Hasan dari Imran bin Hushain berkata, "Kami bersama nabi saw. dalam suatu perjalanan, (kecepatan) perjalanan para shahabat berbeda-beda lalu Rasulullah saw. mengeraskan suara membaca kedua ayat ini: "Hai manusia, bertakwalah kepada Tuhanmu; Sesungguhnya kegoncangan hari kiamat itu adalah suatu kejadian yang sangat besar (dahsyat)," hingga "Akan tetapi azab Allah itu sangat kerasnya." (Al Hajj: 1-2) saat mendengarnya, para shahabat mempercepat binatang tunggangan dan mereka tahu tentang berada dalam ucapan yang dibacakan Rasulullah saw.

Muhammad saw. bertanya, "Tahukah kalian, hari apa itu?" mereka menjawab, "Allah dan Rasul-Nya lebih tahu. Muhammad saw. bersabda, "Itulah hari dimana Allah berfirman kepada Adam, "utuslah utusanutusan ke neraka." Adam bertanya, "Wahai Rabb, apa itu utusan ke neraka?" Allah menjawab, "Sembilan ratus Sembilan puluh sembilan orang masuk neraka sedangkan satu orang masuk surga." Orang-orang ketika itu semuanya berputus asa hingga tidak ada yang menampakkan gigi serinya karena tertawa. Saat Rasulullah saw. melihat kondisi shahabat, beliau bersabda: "Berbuatlah dan bergembiralah, demi Dzat yang jiwa Muhammad berada ditangan-Nya, sesungguhnya kalian bersama bersama dua makhluk, tidaklah keduanya bersamaan dengan sesuatu melainkan pasti memperbanyaknya; Ya'juj dan Ma'juj dan keturunan Adam yang mati serta keturunan Iblis." Imran berkata, "Mereka pun bergembira dengan sebagian hal yang mereka temukan." Beliau saw. bersabda, "Berbuatlah dan bergembiralah, demi Dzat yang jiwa Muhammad berada ditangan-Nya, tidaklah kalian di tengah-tengah manusia melainkan seperti tahi lalat di sebelah unta atau seperti tanda di 
lengan binatang ternak." Abu Isa berkata bahwa hadis ini hasan shahih. (HR. Tirmidzi: 3093)

Dalam hadis ini Muhammad saw. memancing perhatian para shahabat dengan ayat yang memberitakan kiamat. Setelah memperhatikan sejauh mana ayat tersebut dapat menarik perhatian para shahabat, Muhammad saw. lantas menyampaikan stimulus tambahan berupa kejutan melalui pernyataan bahwa 999 dari 1000 orang akan masuk neraka. Tindakan tersebut bertujuan untuk meningkatan atau mempertahankan atensi shahabat.

Beberapa hadis di atas menunjukkan bahwa menampilkan ketidaknormalan dan kejutan dapat menjadi teknik yang efektif untuk menarik atensi. Pada hakikatnya teknik ini menekankan pada daya beda stimulus sehingga ia lebih mudah dikenali dari stimulus yang lainnya. Perbedaan itu tidak selalu diukur secara indrawi seperti kontras warna, tekstur dsb. Apa yang dilakukan Muhammad saw. contoh ketidaknormalan yang tidak diukur dengan indera namun cenderung pada pertimbangan hati dan akal. Misalnya, dalam hadis riwayat Bukhari nomor 1278 dan Muslim nomor 1578 ketika Muhammad saw. mengatakan "wajabat" kepada mayat yang dikenal telah beramal baik demikian pula kepada yang dikenal beramal buruk. Ketidaknormalan dan kejutan dalam konteks ini tidak diukur secara fisik namun ia tetap mampu menarik atensi karena dianggap 'tidak normal' menurut ukuran akal dan hati.

Sesuatu bisa juga dipandang sebagai hal yang tidak lazim atau mengejutkan jika tidak sesuai dengan intuisi komunikan. Intuisi dalam aplikasi KBBI V dijelaskan sebagai kemampuan mengetahui atau memahami sesuatu tanpa dipikirkan atau dipejari. Ibnu 'Arabi, sebagaimana dikutip oleh Khudhori, (2010: 49) menyatakan bahwa kebenaran intuisi lebih unggul daripada apa yang diperoleh indera dan akal. Intuisi hadir sebagai bagian dari fitrah manusia. Ketidaklaziman menurut ukuran intuisi lebih mudah mendapat atensi karena tidak memerlukan proses berpikir panjang.

Beberapa hal yang dapat merangsang intuisi disebutkan dalam Surat Ali-Imran ayat 14.

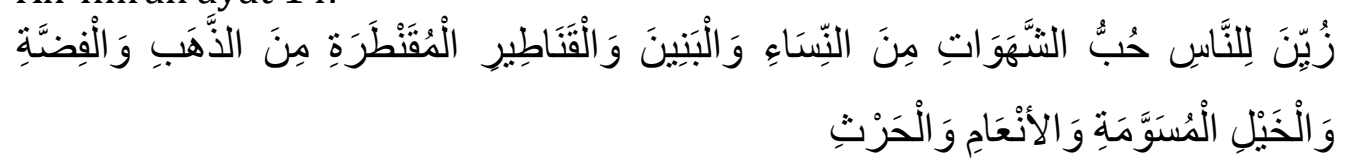

Artinya: Dijadikan indah pada (pandangan) manusia kecintaan kepada apa-apa yang diingini, yaitu: wanita-wanita, anak-anak, harta 
yang banyak dari jenis emas, perak, kuda pilihan, binatang-binatang ternak dan sawah ladang.

Intuisi dapat pula muncul lewat stimulus yang immaterial. Contoh intuisi ini adalah rasa kasih sayang dalam hati seorang mukmin yang beramal baik. Hal ini dinformasikan dalam Surah Thaha ayat 96,

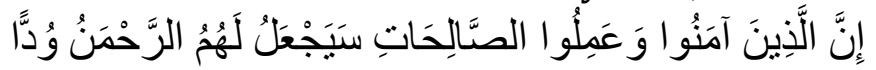

Artinya: Sesungguhnya orang-orang yang beriman dan beramal salih, kelak Allah Yang Maha Pemurah akan menanamkan dalam (hati) mereka rasa kasih sayang.

Ketika Muhammad saw menyebut bahwa mencaci orang tua adalah dosa besar (hadis riwayat Muslim nomor 130), maka para shahabat langsung menaruh atensi pada hal tersebut karena secara intuitif tidak mungkin seorang anak mencaci maki orang tuanya. Ketika Muhammad mendoakan jenazah orang baik dan buruk dengan redaksi yang sama (hadis riwayat Bukhari nomor 1278), atensi shahabat segera muncul sebab secara intuitif manusia tidak akan menyamakan kebaikan dan keburukan. Penyataan atau doa Muhammad saw. dianggap tidak normal dan mengejutkan.

e. Pengendalian atensi dengan memanfaatkan momentum

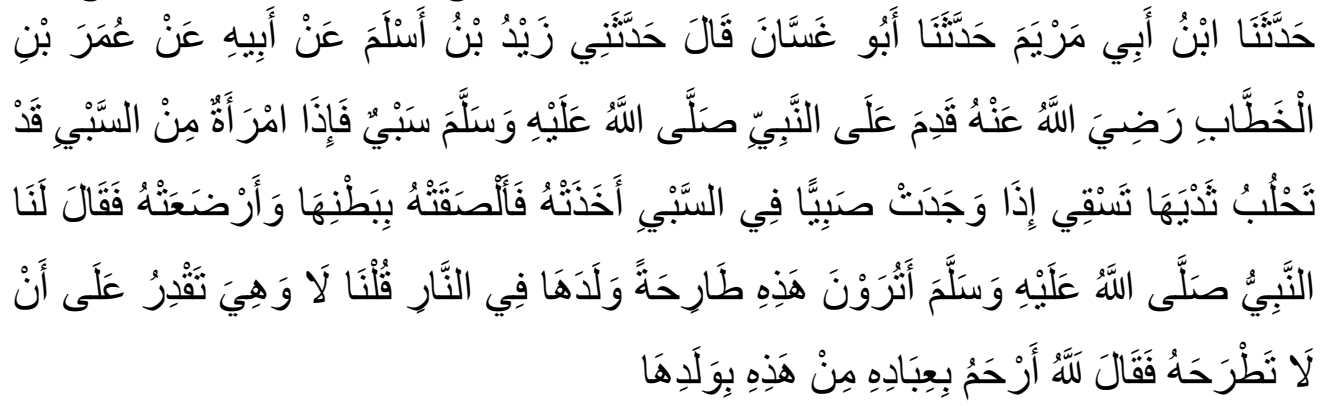

Telah menceritakan kepada kami Ibnu Abu Maryam telah menceritakan kepada kami Abu Ghassan dia berkata; telah menceritakan kepadaku Zaid bin Aslam dari Ayahnya dari Umar bin Al Khatthab radliallahu 'anhu (katanya), "Rasulullah saw. pernah memperoleh beberapa orang tawanan perang. Ternyata dari tawanan tersebut ada seorang perempuan yang biasa menyusui anak kecil, apabila dia mendapatkan anak kecil dalam tawanan tersebut, maka ia akan mengambilnya dan menyusuinya, lalu Nabi saw. bersabda kepada kami. "Menurut kalian, apakah perempuan itu tega melemparkan bayinya ke dalam api?" Kami menjawab, "Sesungguhnya ia tidak akan tega melemparkan anaknya ke dalam api selama ia masih sanggup menghindarkannya dari api tersebut." Lalu beliau saw. bersabda, "Sungguh, kasih sayang Allah terhadap hamba-Nya melebihi kasih sayang perempuan itu terhadap anaknya." (HR. Bukhari: 5540). 
Sesuatu yang menggugah emosi berpotensi menarik atensi. (Jensen, 2008: 189). Peristiwa yang terjadi antara ibu dan anak dalam hadis ini tentu berpotensi menarik rasa iba dan haru orang di sekitarnya. Kondisi terharu yang dialami shahabat adalah wujud awal adanya atensi dari stimulus yang diumpankan Muhammad saw.

Dalam konteks hadis tersebut Muhammad saw. dengan jelas telah berhasil menarik perhatian para shahabatnya menggunakan momentum yang terjadi sehingga mereka antusias terhadap perkataan selanjutnya. Perhatian shahabat ditunjukkan dengan kesigapan mereka menjawab pertanyaan Muhammad saw. Fenomena ini menunjukkan bahwa para shahabat Muhammad saw. memblokir semua stimulus dari kesadaran yakni hiruk-pikuk dalam kerumunan tawanan perang kecuali stimulus tertentu yaitu kejadian ibu dan anak yang ditunjukkan oleh Muhammad saw. Kejadian antara ibu dan anak merupakan momentum yang cocok untuk menarik atensi karena secara intuitif manusia memiliki kasih sayang terhadap sesama.

Muhammad saw. pernah pula menggunakan momentum bulan purnama untuk menarik perhatian.

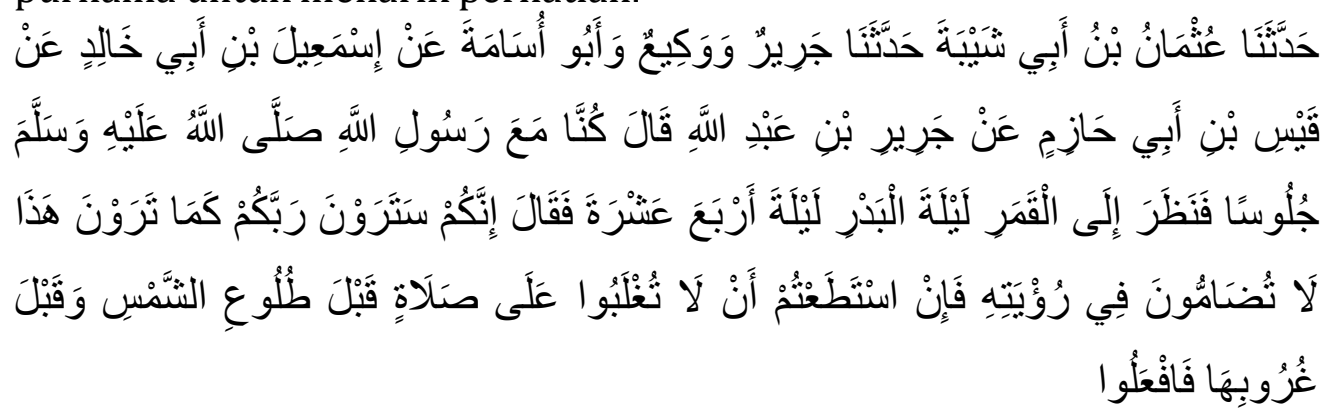

Telah menceritakan kepada kami Utsman bin Abu Syaibah berkata, telah menceritakan kepada kami Jarir dan Waki' dan Abu Usamah dari Isma'il bin Abu Khalid dari Qais bin Abu Hazim dari Jarir bin Abdullah ia berkata, "Kami duduk bersama Rasulullah saw. kemudian beliau melihat bulan purnama, tepatnya malam tanggal empat belas. Beliau bersabda, "Kalian akan melihat Tuhan kalian seperti kalian melihat rembulan ini, tidak ada yang menghalangi pandangan kalian. Jika kalian mampu untuk melaksanakan shalat sebelum terbit dan tenggelamnya matahari, maka lakukanlah."

Selain contoh di atas ada pula riwayat bahwa ketika Muhammad saw. mendengar kecemburuan Sa'adz bin Ubaidah yang berkata, "Seandainya aku melihat ada seorang laki-laki bersama istriku, aku pasti akan memenggalnya dengan sisi pedangku yang tajam!" Muhammad saw. kemudian ia memanfaatkan momentum tersebut untuk menggambarkan kecemburuan Allah kepada umatnya yang berbuat keji. 


$$
\text { أَتَعْجَبُونَ مِنْ غَيْرَةِ سَعْدِ؟ لاَنَنَا أَغْيَرُ مِنْهُ وَاللَّهُ أَغْيَرُ مِنِّى }
$$

Artinya: Apakah kalian takjub terhadap kecemburuan Sa'ad? Aku adalah orang yang lebih cemrburu daripada dia, dan Allah lebih pemcemburu daripada aku. (HR. Muslim: 2755)

Suryabrata (2008: 18) menyatakan bahwa meskipun tingkat atensi seseorang berbeda-beda, namun atensi yang terbentuk secara spontan dari pengaruh situasional akan cenderung berlangsung lebih lama dan lebih intensif daripada atensi yang disengaja. Ketika seseorang dihadapkan dengan realitas unik atau menarik dalam sebuah momentum maka ia akan memberi atensi tanpa paksaaan, tanpa perlu instruksi dari pihak lain.

f. Mendekati atau menyentuh lawan bicara

Mendekati dan/atau menyentuh sering dilakukan oleh Muhammad saw. untuk menjaga atensi shahabat agar tetap fokus pada dirinya. Teknik ini juga akan menimbulkan kesan yang lebih kuat bagi orang yang diajak bicara. Imam Bukhari meriwatkan dari Abdullah bin Mas'ud ia berkata:

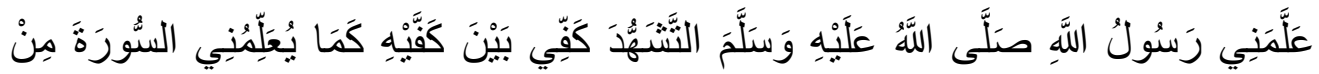

Artinya:"Rasulullah saw. mengajarkan kepadaku tasyahhud, pundakku di antara pundaknya, sebagaimana beliau mengajarkan suatu surat Alquran.". (Bukhari: 609)

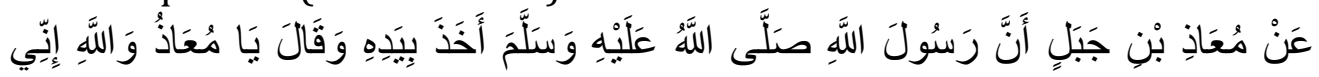

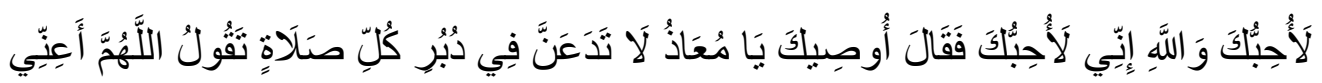

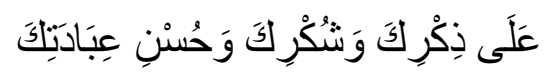

Artinya: dari Mu'adz bin Jabal bahwa Rasulullah saw. menggandeng tangannya dan berkata, "Wahai Mu'adz, demi Allah, aku mencintaimu." Kemudian beliau berkata, "Aku wasiatkan kepadamu wahai Mu'adz, janganlah engkau tinggalkan setiap selesai shalat untuk mengucapkan," Ya Allah, bantulah aku untuk berdzikir dan bersyukur kepadaMu serta beribadah kepadaMu dengan baik." (HR. Abu Dawud: 1301)

Selain memegang tangan atau pundak, Nabi saw. juga pernah menepuk dada lawan bicaranya,

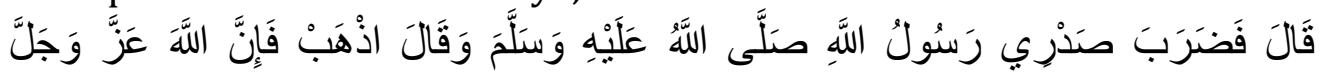

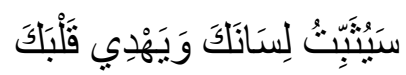


Ali Radhiallah 'anhu berkata; Rasulullah saw. menepuk dadaku dan bersabda: "Pergilah, sesungguhnya Allah azza wa jalla akan meneguhkan lidahmu dan menunjuki hatimu! (HR. Ahmad: 1088).

Woolfolk (2009: 13) memberikan pedoman untuk mendapatkan dan mempertahankan atensi, salah satunya ialah mendekati atau mendatangi peserta didik bukan memanggilnya. Lebih dari itu, apa yang dipraktikkan Muhammad saw. tidak hanya mendekati namun menyentuh peserta didiknya. Hal ini tentu saja lebih kuat pengaruhnya terhadap atensi peserta didik. Sentuhan akan membuang bias-bias jarak antara pendidik dan peserta didik.

Pendengaran dan penglihatan dianggap sebagai indera primer namun sentuhan juga memiliki peran yang sama pentingnya dalam komunikasi. Komunikasi yang melibatkan sentuhan memiliki kelebihan karena salah satu hal yang dapat meningkatkan perhatian terfokus adalah minimnya jarak dan arah, serta rendahnya gangguan dari lingkungan sekitar. Kedua hal tersebut akan terpenuhi ketika sebuah sentuhan atau kedekatan terjadi secara berkesinambungan dalam proses komunikasi.

Menurut Mulyana (2001: 336) sentuhan memliki sifat yang menjadikannya sebagai hal penting dalam strategi dalam komunikasi. Sentuhan dapat membangun kedekatan, keterikatan serta menjadikan pihak yang disentuh merasa dihargai. Sebagaimana disampaikan oleh Jensen (2008: 192) bahwa sesuatu yang memiliki makna personal akan mampu menarik atensinya. Pendapat ini dapat dikaitkan dengan Piramida Kebutuhan Abraham Maslow yang memasukkan kebutuhan akan keterikan dan cinta serta rasa ingin dihargai sebagai hal yang dicari manusia setelah rasa aman. Dengan demikian sangatlah wajar jika lawan bicara Muhammad saw. akan memfokuskan atensi kepadanya selama dialog berlangsung.

Muhammad saw. seringkali mengombinasikan beberapa teknik dalam sebuah penyampaian hadis sehingga Muhammad saw. menjadi lebih kuat menarik dan mengendalikan atensi. Misalnya, memanfaatkan momentum disertai pencitraan ketidaknormalan sebagaiamana doanya untuk mayat ahli kebaikan dan keburukan (Bukhari nomor 1278 dan Muslim nomor 1578). Bahkan, teknik pengendalian atensi yang dilakukan Muhammad saw. sebenarnya sulit untuk diaplikasikan tanpa dikombinasikan dengan teknik lainnya apalagi dipisahkan dengan penerapan jawamiul kalim dan qaulan baligha. 


\section{Kesimpulan}

Dalam mengendalikan atensi peserta didiknya Muhammad saw. menggunakan teknik repetisi, dialog interkatif berisi pertanyaan retoris, memanfaatkan momentum, menyebutkan hal yang global, menampilkan ketidaknormalan dan kejutan serta menyentuh lawan bicara. Muhammad saw. dalam beberapa hadis menggunakan lebih dari satu teknik pengendalian atensi. Kombinasi teknik yang tepat dapat meningkatkan daya tarik stimulus untuk mendapat atensi.

Semua teknik pengendalian atensi Muhammad saw. dikombinasikan dan didukung oleh kemampuan berkomunikasi verbal yang baik. Muhammad saw. memiliki qaulan baligha (kata-kata yang menyentuh hati) dan jawami'ul kalim (kata-kata singkat namun padat makna) serta penjagaan ritme dan tempo bicara (parabahasa atau vokalika).

\section{Daftar Rujukan}

Al-Qaththan, Syaikh Manna, Pengantar Studi Hadits, Cet. 9, Penerjemah: Mifdhol Abdurrahman, Jakarta: Pustaka Al Kautsar.

Bagus, Lorens, Psychology of Cognitive, USA: McGraw-Hill, 1996

DePorter, Mark Reardon dan Sarah Singer, Quantum Teaching: Mempraktikkan Quantum Learning dalam Ruang Kelas, Bandung: Kaifa, 2008

DeVito, Joseph A, Komunikasi Antarmanusia, Edisi ke-5, Penerjemah: Agus Maulana. Jakarta: Professional Books, 1997

Ghuddah, Abdul Fattah, 40 Metode Pendidikan dan Pengajaran Rasulullah, Bandung: Irsyad Baitus Salam, 2009

Hamka, Tafsir Al Azhar, Jakarta: Pustaka Panji Mas, 2008

Hilgart, Introduction for Psikologi, New York: Brace and Inc, 1996

Ilahi, Fadhl, An-Nabiyyul Karim Mu'alim: Bersama Rasul Mendidik Generasi Idaman. Penerjemah: Ahmad Yunus, Jakarta: Pustaka Imam Asy Syafi'I, 2010

Jensen, Eric, Brain-Based Learning, Pembelajaran Berbasis Kemampuan Otak. Penerjemah: Narulita Yusron, Yogjakarta: Pustaka Pelajar, 2008

Johnson, Addie and Robert W. Proctor, Attention, Theory and Practice, New Delhi: Sage Publications, 2004

Matlin, Margaret W., Cognition. USA: Harcourt Brace Publishers, 1994

Muhadjir, Noeng, Metode Penelitian Kualitatif, Yogyakarta: Rake Sarasin, 1996

Mulyana, Deddy, Ilmu Komunikasi: Suatu Pengantar, Bandung: PT Remaja Rosdakarya, 2001

Oetiningsih, The Power of Memory, Jakarta: Erlangga, 2009 
Purwanto, Evaluasi Hasil Belajar, Yogyakarta: Pustaka Pelajar, 2009

Rakhmad, Jalaluddin, Psikologi Komunikasi, Bandung: Rosdakarya, 2015

Sholeh, Khudori, Integrasi Agama dan Filsafat (Pemikiran Epistemologi AlFarabi), Malang: UIN Maliki Pres, 2010

Silberman, Melvin L., Active Learning: 101 Strategi Pembelajaran Aktif. Penerjemah: Sarjuli, Yogyakarta: Pustaka Insani Madani, 2007

Sugiharto, Psikologi Pendidikan, Yogyakarta: UNY Press, 2007

Suryabrata, Sumardi, Psikologi Pendidikan, Jakarta: Pustaka Pelajar, 2001

Titscher, Stefan dkk, Metode Analisis Teks dan Wacana, Pen. Gazali, dkk. Yogyakarta: Pustaka Pelajar, 2009

Woolfolk, Anita, Educational Psychology, Active Learning Edition, Edisi ke10, bag. Ke dua. Penerjemah: Helly P.S dan Sri M. Yogjakarta: Pustaka Pelajar, 2009 